\title{
Externalities in Water Santri Sidogiri Natural Resources Perspective Islamic Economy
}

\author{
Nikmatul Fuadah ${ }^{1}$ and R. Moh. Qudsi Fauzi ${ }^{2}$
}

${ }^{1}$ Magister of Sekolah Pascasarjana, University of Airlangga

${ }^{2}$ Department of Islamic Economics, Faculty of Economics and Business, University of Airlangga

\section{Abstract}

The purpose of this research is to know Pupils externalities on drinking water company, Sidogiri roomates-reviewed by Islamic economic resources. Externalities are Analyzed include positive externalities and negative externalities. Then, researcher will conduct a discussion with Islamic perspective to find out the way of externalities could happen on research object.

This study uses qualitative methods with descriptive case studies strategy. The object of this research is the factory of bottled drinking water Rasta, Sidogiri. This research uses interviews to six informants consisting of leadership of the PT. Sidogiri Mandiri

Corresponding Author: Nikmatul Fuadah

nikmatulima10@gmail.com

Received: 10 February 2019 Accepted: 14 March 2019 Published: 28 March 2019

Publishing services provided by Knowledge E

(c) Nikmatul Fuadah and R. Moh. Qudsi Fauzi. This article is distributed under the terms of the Creative Commons

Attribution License, which permits unrestricted use and redistribution provided that the original author and source are credited.

Selection and Peer-review under the responsibility of the ICIEBP Conference Committee.

\section{G OPEN ACCESS}

Utama, play production manager of PT Sidogiri Mandiri Utama, and the surrounding people as a tool for getting information. After done interviews, research results will be Analyzed by triangulation to get a conclusion. The roomates results of this research conducted by observation and interviews to six informants is finding of positive externalities's domination on the economic and social fields while maintaining the balance of nature in comparison with negative externalities.

Keywords: Externalities, Externalities Positive, Negative Externalities, and Islamic Economic Resources.

\section{Preliminary}

\subsection{Background}

The Industrial Revolution took place in 1750-1850. At this time it happened major changes in agriculture, manufacturing, mining, transportation, and technology and has a profound impact on social, economic and cultural world (Sofiana, 2014). These conditions causing increasingly rapid industrial growth in the world including in Indonesia. But rapid growth is not matched by maintenance of an adequate environment. It takes the industry to balance between the financial aspects and environmental aspects to be example. 
Industrial activity is managing a natural resource that has been set in Industry Act 5 of 1984 the industry is an economic activity that ismanage raw materials, raw materials, semi-finished goods, and or finished goods into goods with a higher value for its use include design activities and industrial engineering. According Kamarol (2017) development activities carried out in various forms of business and / or activities will basically cause the impact on the environment. Development is expected to increase quality of life and whether an action plan development will be detrimental humans and the environment or not. Companies must adjust suitability of development against benchmarks ditetukan by EIA of the government. Development of an industry will potentially have negative effects as well as a positive influence. It is becoming consideration in the establishment of an industry, because in the production process themselves help the process of making a decision on the environmental feasibility of the business plan and / or activity. Suitability of development against benchmarks ditetukan by EIA from the government.

Islam on the other hand is a life that is koprehensif system, which governs all aspects of life, whether in the social, economic and political as well as spiritual life in balance. Islam is a religion that has its own system in dealing with the problems of life, both materially and nomateriil Edwin, et al (2006: 1). Economic activity has also been stipulated in Islam contained in the Qur'an and Sunnah. God has provided all the natural resources on earth. Allah says in the Qur'an. Al-Baqarah: 29 This means:It is God, who made everything on earth for you and He wills (creating) the heavens, and made him the seven heavens. And He has knowledge of all things (Qur'an translation of the Ministry of Religious Affairs, 2010: 5).

In Islam, the economic activities carried out by a person for the welfare of themselves, should not be done by ignoring and sacrificing the interests of others (Mustafa et al 2006: 24). It is already stated in the Qur'an in Surah Al-Hashr 7

That is: "What are the spoils (fai-i) that God gave to His Messenger (of the property) from the people of the towns then is for God, for the apostle, kinsfolk, orphans, the poor and people who are on the way, so that it may not circulate among the rich among you. what is given unto the Apostle, then accept it. leave what he forbids. and fear Allah. Verily Allah Amat harsh punishment. (Qur'an translation of the Ministry of Religious Affairs, 2010: 546)"

According to Edwin et al (2006: 24) paragraph above explains that economic activities by each individual unntuk welfare himself should not ignore the latter. This principle must be reflected on every individual and institutional policy, when economic activity. Industry has the disadvantage that imbalance, whereas in Islam are taught to maintain 
a balance in all aspects. To solve these problems will require the placement of Islamic values in the world IndustriSesungguhnya God is to be worshiped and obeyed is giving the gift to you to make the whole enjoyment of the earth for the benefit of you. Then, simultaneously with the creation of the earth with all its benefits, Allah created the seven heavens decker. In it there is nothing you can see and nothing that you can not see. And Allah is well acquainted with all sesuatu.Sesungguhnya God is to be worshiped and obeyed is giving the gift to you to make the whole enjoyment of the earth for the benefit of you. Then, simultaneously with the creation of the earth with all its benefits, Allah created the seven heavens decker. In it there is nothing you can see and nothing that you can not see. And Allah knows everything.. Then, simultaneously with the creation of the earth with all its benefits, Allah created the seven heavens decker. In it there is nothing you can see and nothing that you can not see. And Allah knows everything.. Then, simultaneously with the creation of the earth with all its benefits, Allah created the seven heavens decker. In it there is nothing you can see and nothing that you can not see. And Allah knows everything..

According to Rosen (in Mulyaningrum, 2005) that externality occurs when the activity of a single unitary entity which affect the welfare of other events beyond market mechanisms (non-market mechanism). Unlike effect transmitted through the market mechanism, externalities can affect economic efficiency.

The importance of externalities in an industry analysis is to determine the performance of a company or industry in giving to the community and environment, both positive and negative impacts (Elfira, 2016). Positive externalities occur when the activity carried out by a person or group of benefits on individuals or groups (Sankar, 2008). The negative externality occurs when an individual or group activities produce harmful effects for others.

An industry has a problem of imbalance in some aspects such as social, environmental, economic, political and financial, when juxtaposed with Islamic values that promotes balance in various ways, it will produce a healthy industry. Examples of companies that will be a model in the bottled water industry is Santri drinking water. As a pilot company in the bottled water industry has plenty of externalities Pupils can diteleiti.

Pupils water company including business units owned Kopontren Sidogiri Ponpes Sidogiri served as a main financial source Sidogiri boarding school, founded in 1961 by KH. Sa'doellah Nawawi and incorporated cooperative in 1997.Pupils drinking water springs located in the village Umbulan, Pasuruan. Umbulan springs in the village is famous for being one of the best water in the world. Within a day, the capacity of this mill machine can produce 9,000 glasses of $250 \mathrm{ml}, 4500$ gallons and 126,000 
bottles per day. So in a month Pupils drinking water plant capable of distributing all of its products to a wide range of areas, such Probolinggo, Malang, Surabaya, Situbondo, Bondowoso, Jember, Lumajang and others.

The drinking water treatment plant managed by Islamic-based parties lodge, where some of the activities carried out by operators to support religious activities around the factory and outside the factory. This suggests a positive action, so here researchers want to learn more related externalities that occur as a result of industrial activity Pupils drinking water treatment. Eksternlitas externalities analyzed include positive and negative externalities. Then the researchers will conduct discussions with the Islamic perspective to determine how the principles of Islam in governing the use and pemeiharannya.

\section{Theoretical Basis}

Fisher (1996) says that the externality occurs when the activity of economic operators (both production and consumption) affect the welfare of economic agents and existing events occur outside the market mechanism. So that when the externalities, the private choices by consumers and producers in the private markets do not generally produce something that is economically efficient.

Environmental quality by Jaribah (2006: 403) in the economic development will be realized with the establishment of an Islamic environment in all aspects of life, where some of the pillars of the environment carry the most important.

Natural resources are all forms of natural womb, as a favor and grace of Allah that can be exploited and processed human survival and gain support purposes other sentient beings. The natural resources are mineral resources, marine resources, forest resources, and others. The Qur'an never informed of everything in nature is just as environmental elements alone, but the whole is a source of resources that benefit both humans and other creatures (Ulfah 2008: 6).

\subsection{Indicator assessment externalities}

The industrial sector is believed to be the sector that will lead other sectors in an Economic Affairs towards progress (Dumairy, in siti, et al 2016) Here are some of the indicators used in this study.

\section{Patterns of Economic Development}


Development according to Tjokroamidjoyo (in Sutrisna 2008), which as a sociocultural changes, then industrialization as an aspect of development would change the structure and function of civil society. This means that industrialization is not only able to raise the economic growth is quite high, but also raises other matters in people's lives such as population growth is quite high due to the arrival of people from other regions who serves as labor in factories, there is a pattern shift in the local economy, shifts in lifestyle as well as other problems that actually is the interrelation and accumulation of the three issues.

\section{Employment}

According to Khan (2014: 229) in the Islamic perspective there is no human resources can be assumed to be unemployed. Within the framework of Islam, it is very important that every individual seek economic activity for himself because

(a) Not driven for unemployed

(b) Necessary to support themselves and their families, do not rely on others

(c) Are needed to help poor people in society

(d) Required to provide resources to preach Islam

Therefore, all the able-bodied physical-spiritual and are at working age are required to search for compatible economic activities. The development objective is to generate opportunities that can absorb labor. So in entrepreneurial activity or industrialization able to help themselves and others in creating opportunities in the workforce.

3. Revenue Improvement Society

Industrialization is defined as a structural transformation that exist in a country. The industrialization process itself can be defined as the process of change in the economic structure in which there is an increase in the industrial sector's contribution to consumer demand, GDP, exports and employment (Chenery, in Tambunan 2006). industrialization guarantee the continuity of the process of long-term economic development with high economic growth and sustainable development.

While the negative externalities

1. The industrial waste According to KBBI (line 2017) is the rest of the production process or materials 
that does not have value or not worthwhile for ordinary purpose or in the manufacture or use.The impact of industrial waste on the environment is very dangerous addition of environmental contaminates can cause radiation mill waste, odor and heat (Supratini, 2002).

2. Air pollution.

Air pollutants are various types of gaseous compounds and particles whose existence in a certain concentration can be harmful to humans. (Gusnita, 2012)

3. Inconvenience for surrounding communities

The intensity or volume that exceeds acceptable levels. Generally sound louder increasingly undesirable. Sound began to be uncomfortable at a rate of $65 \mathrm{~dB}$ and begin to interfere when it reached the level of $85 \mathrm{~dB}$ and $95 \mathrm{~dB}$ is very disturbing and can damage hearing (Gusnita, 2012).

\subsection{Research methodology}

This study uses qualitative research due to answer questions on the formulation of the problem in a comprehensive and deep understanding of externalities in drinking water perusaahaan Pupils in Sidogiri. According to Yin (2009: 8) qualitative research strategy which has five experiments, surveys, analysis of archives, historical, and case studies. In this study, the authors use case studies to understand the strategy of the issues examined. According to Yin (2009: 18) case study is an empirical inquiry that investigates the phenomenon in the context of real life, when the boundaries between phenomenon and context do not appear explicitly; and where the evidence multisumber utilized.Types and Sources of Data

According Kuncoro (2003) that the type and source of research data are important factors into consideration in determining the methods of data collection, the data used in this study include:

1. Primary data in this study was obtained from interviews with key informants (key informants) to determine in detail the phenomenon occurs, then the key informants in this study are as follows:

(a) Leader

(b) Local communities.

2. Secondary data in this study were obtained from books, journals, newspapers, and documents or reports ever conducted research activities relating to externalities 
and environmental research on the Islamic perspective. The question to ask is a question in accordance with the purpose of research, which is related to the externalities of their water company factory activity Pupils

\subsection{Data collection technique}

According to Yin (2012: 103) that qualitative research with case study strategy can be based on six sources of evidence that can be used as a focus for data collection is to document, archive footage, interviews, direct observation, observation participation and physical devices. In this study researchers used interviews and other supporting data collection to collect the necessary data. The steps performed in the data collection procedure is as follows:

1. Getting started before in the field

Identification of problem formulation and research purposes to limit the direction and intent of this research. Analyzes were also conducted on the results of preliminary studies or secondary data that will be used to focus penelitian.Namun thus the focus of research is still tentative and will be developed after investigators went in and while in the field.

2. The current stage in the field

(a) Interview

(b) Observation

(c) Document

\subsection{Validity of engineering data}

Sugiyono (2012: 274), Triangulation source as a credibility test conducted by researchers with the means to check the data that has been obtained through several sources. Triangulation techniques conducted by researchers by checking the data to the same source with different techniques. For example, the data collected from interviews, and checked by observation, and documentation. In addition, the researcher triangulation can also be done by checking the results with the results of other researchers who did the same data collection 


\subsection{Data analysis technique}

After doing research data collection, the data can be analyzed to get a conclusion. The data obtained from the interviews, observations, and documents will be analyzed and processed based on the basic theory and literature used in the study.

According to Miles and Huberman (in Sugiyono, 2012: 247-253) that explains there are three processes, namely:

\section{Reduction of Data}

Data reduction means summarizing, choose things that are fundamental, focusing on things that are important, look for themes and patterns. Thus, the data that has been on the reduction would give a clearer picture, and facilitate researchers to conduct data collection selanjutya, and look for it when necessary. Data obtained from interviews in the form of recorded interviews, observation and documentation of the interview which is then translated into written form.

\section{Presentation of Data}

Once the data is reduced, the next step is to present the data. Presentation of data is a set of structured information that gives the possibility to draw conclusions and taking action.

\section{Withdrawal conclusion}

The data has been presented, will be drawing conclusions and verification. Inferences made to answer questions that have been formulated in the formulation of the problem before. Then, the verification take place during the research process to obtain valid and consistent evidence in order to be justified.

\section{Results and Discussion}

In this sub researchers will discuss how externalities that occur in the community, the following is an indicator that has been described in Chapter 2

\section{Patterns of Economic Development}

Not a lot of people who come from outside, is recorded in a factory environment bottled water Pupils informant fifth there are 30 heads of families, due to the utilization of manpower utilize indigenous people around the plant, while workers who are not residents of the village of Umbulan lived not far from the place work. 
The economic growth rate in 2016 to the preparation of this report have not yet submitted Pasuruan BPS data, so that the last data used in 2015 (http:// pasuruankab.go.id accessed on 23 January 2018). Economy in the district of Pasuruan in 2015 grew by $5.47 \%$. The conditions show a slowdown compared to 2014 , which grew by $6.69 \%$. Sver the past two years Pasuruan economic growth from 5.38 in 2015 to 5.44 in 2016.

\section{Employment}

Employment that occur are utilizing residents around the plant, the area where the factory site Winongan District of bottled water Santri.

What educational background as well as the last? Bottled water factory in selecting labor Pupils do not see the background even all considered equal and all trained from the beginning of production, only to a few experts were taken in accordance with his expertise. Labor drinking water plant that originally Pupils many unemployed simply because they just graduated from junior high school and even elementary so in their job search in a still difficult to rely on their expertise.

\section{Revenue Improvement Society}

As many as 471 springs scattered throughout the district, with the largest water sources in the district is Umbulan Winongan. Utilization Umbulan springs not only meet the needs of residents of Pasuruan, but also other areas in East Java province, among others Pasuruan, Sidoarjo regency, and Surabaya. There are also springs Winongan Banyu Biru in the district. On the slopes of the hills were encountered depressed artesian wells (artesian) or not depressed (http://pasuruankab.go.id accessed on 23 January 2018).

Aside from a few people who are initially unemployed labor. Some communities are able to take advantage of the existence of such pabrikt. Penliti see there are people who opened the shop around the factory and can provide lunch around more than 100 servings per day, they claimed to be lucky with the plant they can increase the income of opening the business to open shop.

In addition to the assessment of the negative externalities.

1. Industrial waste

Factory students do not emit hazardous waste, the factory has been managing such waste so that waste water released does not contain harmful substances.

2. Air pollution. 
Pupils factory does not issue thick smoke and disturb the surrounding communities, so that the surrounding community and environment safe from air pollution.

\section{Inconvenience for surrounding communities}

Peoples said he did not feel disturbed by atapun factory activity was noisy with activity of the plant. In because the distance to the entrance gate factory sehinggan far enough not too hear people factory activity. Even residents who reasonably close to the plant are also not bothered, because not too noisy factory activity in the community.

Data case of patient visits to health centers and its network of nature recorded electronic recording system software SIMPUS (PHC Management Information System) data obtained in 2014 the top 10 most prevalent diseases. Ranked first in the cases of ARI that is equal to $26.11 \%$ and the lowest at $4.47 \%$ konjungtifitis case).

The decline in the case of health, especially in the respiratory tract, shown in 2014 amounted to $26.11 \%$ and in 2015 fell by $24 \%$. Pupils plant so here is safe karenan decrease in the number of people who complain due to several illnesses in 2014 to 2015.

TABLE 1: Assessment of Externalities.

\begin{tabular}{|c|c|c|c|}
\hline NO & Information & appraisal & Evidence \\
\hline & Positive & & \\
\hline 1 & $\begin{array}{l}\text { The pattern of economic } \\
\text { development }\end{array}$ & $\begin{array}{l}\text { Indicated by the data from } \\
\text { BPS explaining economic } \\
\text { growth in Pasuruan }\end{array}$ & BPS 2016 Pasuruan \\
\hline 2 & Employment & $\begin{array}{l}\text { There, because the use of } \\
\text { residents around the plant }\end{array}$ & $\begin{array}{l}\text { Based on interviews of } \\
\text { informants }\end{array}$ \\
\hline \multirow[t]{2}{*}{3} & Increased revenue & There is & $\begin{array}{l}\text { Based on the information } \\
\text { Pasuruankab.go.id }\end{array}$ \\
\hline & Negative & & \\
\hline 1 & Waste & $\begin{array}{l}\text { It does not pollute the } \\
\text { environment }\end{array}$ & $\begin{array}{l}\text { Evidenced by the data rate } \\
\text { of the health of Pasuruan } \\
\text { District Health Office in } \\
2014 \text { and } 2015\end{array}$ \\
\hline 2 & Pollutant & $\begin{array}{l}\text { The smoke was not thick } \\
\text { and do not disturb }\end{array}$ & $\begin{array}{l}\text { Evidenced by the data rate } \\
\text { of the health of Pasuruan } \\
\text { District Health Office in } \\
2014 \text { and } 2015\end{array}$ \\
\hline 3 & public inconvenience & There is no & $\begin{array}{l}\text { Based on interviews with } \\
\text { informants }\end{array}$ \\
\hline
\end{tabular}




\subsection{Discussion on natural resources}

According Sutikno and Maryuani (2006: 69) The process of industrialization carried out in several countries show the implications deplete natural resources and the deterioration of the environment.The concept of EIA study the impact of development on the environment and the environmental impact of development based on ecological kosnep which is generally defined as the study of the interaction between the living and the environment (Kusumawaradani, 2008).

Bottled water factory Pupils take advantage of natural resources, namely groundwater. Bottled water factory Pupils collect water from springs in the village Umbulan within just 7 meters from the plant and the surrounding community. In the factory production process students have a permit for use of groundwater and plans to cooperate with the Department of Local Linngkungan in conservation issues that have SNI certificate, ISO, and SIPA, so that the pick up and reuse natural resources in accordance with the standards that already apply.

\section{Conclusion}

Based on the research results can be concluded that that occur in the field as follows: Externalities that occur in the bottled water factory Pupils Sidogiri is positive. In tunjukkannya positive response from the local community factories, such as their employment and the local community feel benefited. During the construction of the plant is much that still gives negative impacts on the surrounding communities, such as stinging waste, pollution excessive air, noise and heavy traffic. The neighborhood around the plant running with a balanced, visiblethe conditions of the river is maintained clean. Village Meliihat Umbulan has the best springs in Pasuruan.

\section{References}

[1] Abdi, Mohammad. 2016. Indonesian bottled water industry could be the largest in ASEAN. (Article online), (http://industri.bisnis.com accessed on 24 September 2017)

[2] Aditya.2016. Drinking Water industry Packaging Indonesia Could Be the Biggest ASEAN, (Article online), (http://agro.kemenperin.go.id/3366-Industri-Air-MinumKemasan-Indonesia-Bisa-Jadi-yang-Terbesar-di-ASEAN accessed on 20 December 2017)

[3] Translation Karim Al Qurannul Ministry Agama.2010 
[4] Affiffudin, Beni Ahmad Saebani. 2009, Meetodologi Research Kualitatif.Bandung: Faithful Reader.

[5] Agency for Development and Language Development. 2008. Indonesian Dictionary: Impact. (Online), (http://kbbi.web.id/norma, accessed 22 September 2017).

[6] Agency for Development and Language Development. 2008. Indonesian Dictionary: industrial waste. (Online), (http://kbbi.web.id/norma, accessed 22 September 2017)

[7] Dzaki, Aulia and sugiri. Externalities 2015.Kajian Industrial Fumigation Fish In Bandarharjo District of Semarang Utara urban village. PWK Technical Journal Volume 4 Number 1.

[8] Edwin, Mustafa, dkk.2006. Exclusive introduction of Islamic Economics. Jakarta: Kencana Prenada Media Group.

[9] Emil.2016.Permasalahan Environment Company (online). (Pasuruankab.go.id accessed on 21September2017).

[10] Fanani, Dicky. 2017 Water Supply Company Info Pupils. (Online). (http:// airmineralsantri.co./p/info-perusahaan.html, Accessed on September 19, 2017)

[11] Fisher, RC 1996. State and Local Public Finance.Irwin.New York

[12] Gusnita, Dessy. 2012. Heavy Metals Pollution of Lead (Pb) In The Air And Effort Elimination of Leaded Gasoline. Field researchers Atmospheric Composition, LAPAN

[13] Huda, Nurul, et al.. 2006. Macroeconomic Islam. Jakarta: Gema Insani.

[14] Jaribah, Ahmad Al-Haritsi.2006. Economic Jurisprudence Umar bin Al Khatab. Jakarta: Al Kauthar.

[15] Jonaidi, Arius.2012. Analysis of the Economic Growth and Poverty in Indonesia. Journal of Economic Studies

[16] Kamarol, Sumadi Yakin.2017. Environmental Impact Assessment (EIA) For Instruments And Environmental Pollution Prevention. Badamai Law Journal, Vol. 2, Issues 1.

[17] Karyoedi, Mochtarram.2006.Eksternalitas And Transaction Costs In Market Mechanism In Development Land And Property In Urban Area Bandung. Journal of Urban and Regional Planning.

[18] Khan, M. Fahim.2014. Essay-Essays Islamic Economics; translated by Suherman Rosyidi.Jakarta: Rajawali Pers.

[19] Kuncoro, Mudrajad.2003. Research Methods for Business and Ekonomi.Jakarta: Erland

[20] Kusumawardani, Dean, et al. 2008. The Economics of Natural Resources and Environment. Surabaya: FE Airlangga University. 
[21] Economic Mulyaningrum.2005.Eksternalitas In AlamBerkelanjutan Tourism Development (Case Study in Nature Baturaden region - Purworkerto, Banyumas regency, Central Java Province).skripsi.: Faculty of Economics, University of Bengkulu, Indonesia.

[22] Muri, A, Joseph. 2014. Quantitative Methods, Qualitative Research Gabugan.Jakarta: Prenada Media (Division Kencana).

[23] Prasetya, Ferry. 2012. Module Public Economics: Theory of Fiscal Federalism Part VII: Malang. UB's Faculty of Economics and Business.

[24] Language Center. 2008. Indonesian dictionary. Jakarta: Ministry of Education and Culture.

[25] Republic of Indonesia. 1982. Act No. 4 Article 5 of 1982 on Natural Sumbedaya. Statute In 1982 the Secretariat of State. Jakarta

[26] Republic of Indonesia. 1984. Law No. 5 of 1984 regarding Industry.. Statute 1984. State Secretariat. Jakarta.

[27] Sankar, U. 2008.Enviromental Externalities. (Online).

[28] (http://coe.mse.ac.in/dp/envt-ext-sankar.pdf, Accessed on 11 December 2017).

[29] Sofiana, Yunida.2014.Pengaruh Industrial Revolution Against Development of Modern Design. Humanities Journal Vol.5 2

[30] Sugiyono. 2012. Business Research Methods. Bandung: Alfabeta.

[31] Sutrisna, Endang.2008. Impact of Industrialization Against Social Aspects Economic Community. Journal of Industrial and Urban (Online) (http://file.upi. edu/Directory/FPIPS/JUR._PEND._GEOGRAFI/197210242001121BAGJA_WALUYA/ GEOGRAFI_EKONOMI/Dampak_Industri_thdp_PD.pdf pad accessed on 26 September 2017).

[32] Siti, Tanti Rochman, dkk.2016. Analysis of Industrial Sector Labor Absorption In Java Tengah.JIEP

[33] Supraptini. 2002. Effects of Industrial Waste to the Environment in Indonesia. Media Volume XII Health Research Volume 2

[34] Maryuani.2006.Ekonomi sutikno and Natural Resources. Surabaya.Malang: Agency Publisher Faculty of Economics. Brawijaya University.

[35] Tambunan, Tulus. 2006.Industrial development and industrialization policy in Indonesia Since the New Order Up Post-Crisis, Kadin Indonesia-JETRO

[36] Tjokroamidjojo, Bintoro. 1989. Theory of the National Development Strategy. Jakarta: Mount Agung Soemarwoto, Otto. 2001. Ecology, Environment and Development. Jakarta: Bridges. 
[37] Ulfah, Utami. 2008. Natural Resource Conservation and Sains.Malang Islamic Perspective: UIN-Malang Press..

[38] Wignjosoebroto, Sritomo 2003. Introduction to Engineering \& Industrial Management First Edition. Jakarta: To widya,

[39] Yin, Robert K. 2009. Case Study Design and Methods. Jakarta: Rajawali Pers.

[40] _ 2012. Case Study Design and Methods. Jakarta. PT: King Grafindo Persada.

[41] __ 2014. Case Study Design and Methods. Jakarta. PT: King Grafindo Persada. 